\title{
The influence of active involvement on learning outcomes of physics pre-service teachers: A case study of blended learning on statistics course
}

\author{
Andista Candra Yusro ${ }^{1, a, *}$, Mislan Sasono ${ }^{1, b}$, Gilang Primayoga ${ }^{2, c}$ \\ ${ }^{1}$ Physics Education Department, Universitas PGRI Madiun. \\ Jalan Setiabudi No.85, Kota Madiun, Jawa Timur, 63118, Indonesia \\ 2 Jaringan Information System and Networking Unit, Universitas PGRI Madiun. \\ Jalan Setiabudi No.85, Kota Madiun, Jawa Timur, 63118, Indonesia \\ a andista@unipma.ac.id, b mislan@unipma.ac.id, c gilang@unipma.ac.id. \\ * Corresponding Author.
}

Received: 20 February 2020; Revised: 5 March 2020; Accepted: 31 March 2020

\begin{abstract}
This research aimed at identifying the influence of active involvement on blended learning for Statistics course on the learning outcomes of Physics pre-service teacher. This research also attempted to depict the benefits and challenges during the implementation of blended learning in the higher education context, particularly the implementation of blended learning for Statistics course among Physics pre-service teachers. The sample of this research was the entire students of Physics education department who attended Statistics course in the Fifth semester. Based on the results of the research, the active involvement of Physics pre-service teachers during blended learning session on Statistics course contributes as much as $56.5 \%$. While the correlation equation obtained was $Y=$ $44.509+0.503 \mathrm{X}$. The average responses of blended learning given by the Physics preservice teacher on Statistics course was $81.5 \%$. The implementation of blended learning for Statistics course improves the active involvement of Physics pre-service teachers.

Keywords: physics pre-service teacher, blended learning, statistics course
\end{abstract}

How to Cite: Yusro, A. C., Sasono, M., \& Primayoga, G. (2020). The influence of active involvement on learning outcomes of physics pre-service teachers: A case study of blended learning on statistics course. Momentum: Physics Education Journal, 4(1), 30-37. https://doi.org/10.21067/mpej.v4i1.4194

\section{Introduction}

The emergence of industrial revolution 4.0 provokes a significant influence on the education aspect. Preparing pre-service teachers with the ability to master ICT is essentially substantial. These days, an ICT-based learning approach, starting from the elementary school to higher education, is inevitable. The implementation of an ICT-based learning approach during the learning process by lecturers is highly required, particularly in Faculty of Teacher's Training and Education to provide a qualified learning and prospective graduate (Santoso, Yusro, Malawi, Hanif, \& Kokotiasa, 2019). In the industrial revolution 4.0, preparing Physics pre-service teachers with the ability to master ICT offers them a wide opportunity to compete to pursue their professional career (Yusro, 2018).

A rapid development of technology these days offers an abundant opportunity of innovation and improvement for the aspect of education (Muis \& Bahri, 2018). Through the application of technology, it creates a more efficient and effective learning process. Recently, the application of technology in the education aspect, particularly blended learning, starting from the elementary school to higher education is significantly increasing (Jeffrey, Milne, Suddaby, \& Higgins, 2014). This condition is supported by the proof that blended learning is better than online classroom or face-to-face meeting 
(Kim, Bonk, \& Oh, 2008; Kirna, 2014; Kusni, 2010; Mendez \& Gonzalez, 2011; Murni \& Hodijah, 2016; Sofiana, 2015).

The application of blended learning during Statistics course for Physics pre-service teacher was started on the academic year 2019/2020. This is in line with the previous online learning program which was funded by SPADA grant scheme for Basic Physics course (Hudha et al., 2018). The program was remarkably implemented and obtained a positive response from the students. In addition, the supplementary facilities for supporting the implementation of blended learning have satisfied the minimum standard and thus, the blended learning could be implemented during the learning process on the odd semester of 2019/2020 academic year. Combining face-to-face learning approach and online learning offer a noteworthy opportunity for students to study and acquire information (Alammary, Sheard, \& Carbone, 2014; Jeffrey et al., 2014). Active learning is a primary objective of the blended learning implementation (McCray, 2000). A hybridization is a concept carried out to combine both face-to-face conventional learning and online classroom. Blended learning offers an easy channel for both teacher and student to have flexible communication and information sharing, either in the classroom or the outside classroom (Divayana, 2017).

The implementation of blended learning is remarkably relevant in the context of higher education. It is in line with the research results conducted by (López-Pérez, Pérez-López, \& RodríguezAriza, 2011; Porter \& Graham, 2016; Porter, Graham, Spring, \& Welch, 2014; Vaughan, 2007). The implementation of blended learning requires a central and sharp focus of teacher to balance both online learning and conventional face-to-face learning (Jeffrey et al., 2014). However, as a matter of fact, blended learning is rarely implemented for Statistics course that plays an essential role of research proposal writing and thesis writing.

Blended learning offers an opportunity to improve student's active involvement in the learning process (Mubarok, 2015; Purwitasari, Astawa, \& Sudiarta, 2019; Widiyanto, 2015). Student's active involvement during the learning process represents a considerable interaction (Effendi, 2016). The considerable interaction of students creates a more conducive learning situation and thus, each student is able to show their ability optimally. Therefore, the combination of face-to-face learning and online learning within the blended learning implementation is expected to be able to improve active involvement of Physics pre-service teacher.

This research took Statistics course since it is one of the essential research skill courses that is obligatory to be taken by Physics pre-service teachers. In addition, it is based on the curriculum on the Academic Guidebook 2017. Statistics course for Physics pre-service teachers is expected to assist them in writing their research proposal as well as their thesis writing in the end of academic term (Afifah \& Wicaksana, 2017; Subekti, Untarti, \& Muhammad, 2016). In addition, Statistics course is beneficial for them when they serve as a teacher later, particularly when dealing with data of action research. The desired objective of Statistics course for Physics pre-service teachers is to prepare the students the ability to conduct a research related to Physics education in the form of studies and evaluation of Physics learning by using quantitative and/or qualitative procedure to create a problem-solving related to Physics learning issues and is reported in the form of scientific paper. According to the desired objective above, Statistics plays as an essential role for Physics pre-service teacher since it offers the students the ability about mathematical communication (Subekti et al., 2016).

This present research aimed at describing the influence of active involvement exhibited by Physics pre-service teachers in attending a blended learning session on Statistics course on the learning outcomes. In addition to identify the influence of the active involvement, this research results intends to provide a depiction regarding the implementation of blended learning during Statistics course that includes: the aspect of student's response and the challenge and obstacle of blended learning. It further aimed at obtaining an actual depiction of blended learning implementation from the perspective of students (Physics pre-service teachers), how uncomplicated the students when learning through blended learning as well as the interaction established between the lecturer and students. 


\section{Method}

This research was conducted on Physics pre-service teachers who attended Statistic course on the odd semester of the 2019/2020 academic year. The sample of this research was the entire students who attended Statistics course and it involved 13 students. To obtain a data regarding the active involvement of students during the learning, it took an attending data of students within e-learning and face-to-face learning in the classroom. The e-learning feature used in this study accommodates the lecturers to obtain reports on student activities during the lecture sessions. The response related to statistical learning using blended learning was obtained from a questionnaire given to students at the end of the lecture sessions.

Statistics tests in this study employed simple regression and correlation (Draper \& Smith, 1998; Seber \& Lee, 2012).The data analysis of the relationship and the effect of active involvement of Physics pre-service teacher in blended learning activities on learning outcomes was carried out by using IBM SPSS 24 (Field, 2009; Liu, Kuang, Gong, \& Hou, 2003). Where this analysis was intended to determine whether there is an influence on the active involvement of Physics pre-service teachers on the learning outcomes of Statistics course. Additionally, it intended to find out how much the contribution of active involvement of Physics pre-service teachers in blended learning activities towards the learning outcomes of Statistics course, and further formulated a correlation equation.

\section{Results and Discussion}

The data about the active involvement of Physics pre-service teachers in the blended learning activities in Statistics course during the odd semester of the 2019/2020 academic year was obtained from a combination of e-learning session and face-to-face session. The data about learning outcomes of Physics pre-service teachers in this research was the final score before it was converted into the AE scale. The active involvement of Physics pre-service teachers in the implementation of blended learning was reflected in the reports obtained from the moddle-based e-learning system, where it automatically generated reports of how many times students attended e-learning session. In addition, the active involvement of Physics pre-service teachers wa also reflected in the collection of independent assignments in the form of a study of statistical data in the thesis/final project that was obtained from the library. Punctuality of students in collecting assignments, as well as activities in discussion forums in the moodle system were also taken into account as the research data.

The activity covered an access to teaching material resources prepared by lecturers in each meeting in e-learning session. In detail, the report results that were exported from the system related to the active involvement of Physisc pre-service teachers on the e-learning session was reflected as shown in Figure 1.

Statistics course session through blended learning demands Physics pre-service teacher to be disciplined on the time that has been arranged before, particularly in the online learning session. In addition to obtaining a lesson material delivery and discussion with the lecturer, the students were asked to conduct uncomplicated examination on the statistical data of the unpublished undergraduate's thesis/thesis/final project in the university library. Such activity offers a direct experience how to practice statistical analysis and examination procedures they obtained during the course session. In addition, it allows the students to think critically and perform scientific attitude. This activity that was combined by e-learning session demanded Physics pre-service teacher to have active involvement during the entire course session. According to the examination conducted by Physics preservice teachers, most of the statistical analysis used by students in the undergraduate's thesis/final project (as much as 90\%) was parametric statistical testing. Non-parametric statistical testing was rarely used by the students during the undergraduate's thesis writing or final project. This is due to that Statistics played a role as primary procedure to assist students in making decision regarding research hypothesis.

The Table 1 illustrates the learning outcomes and the active involvement score of Physics preservice teacher during blended learning session on Statistics course. 
Momentum: Physics Education Journal, 4 (1), 2020, 33

Andista Candra Yusro, Mislan Sasono, Gilang Primayoga

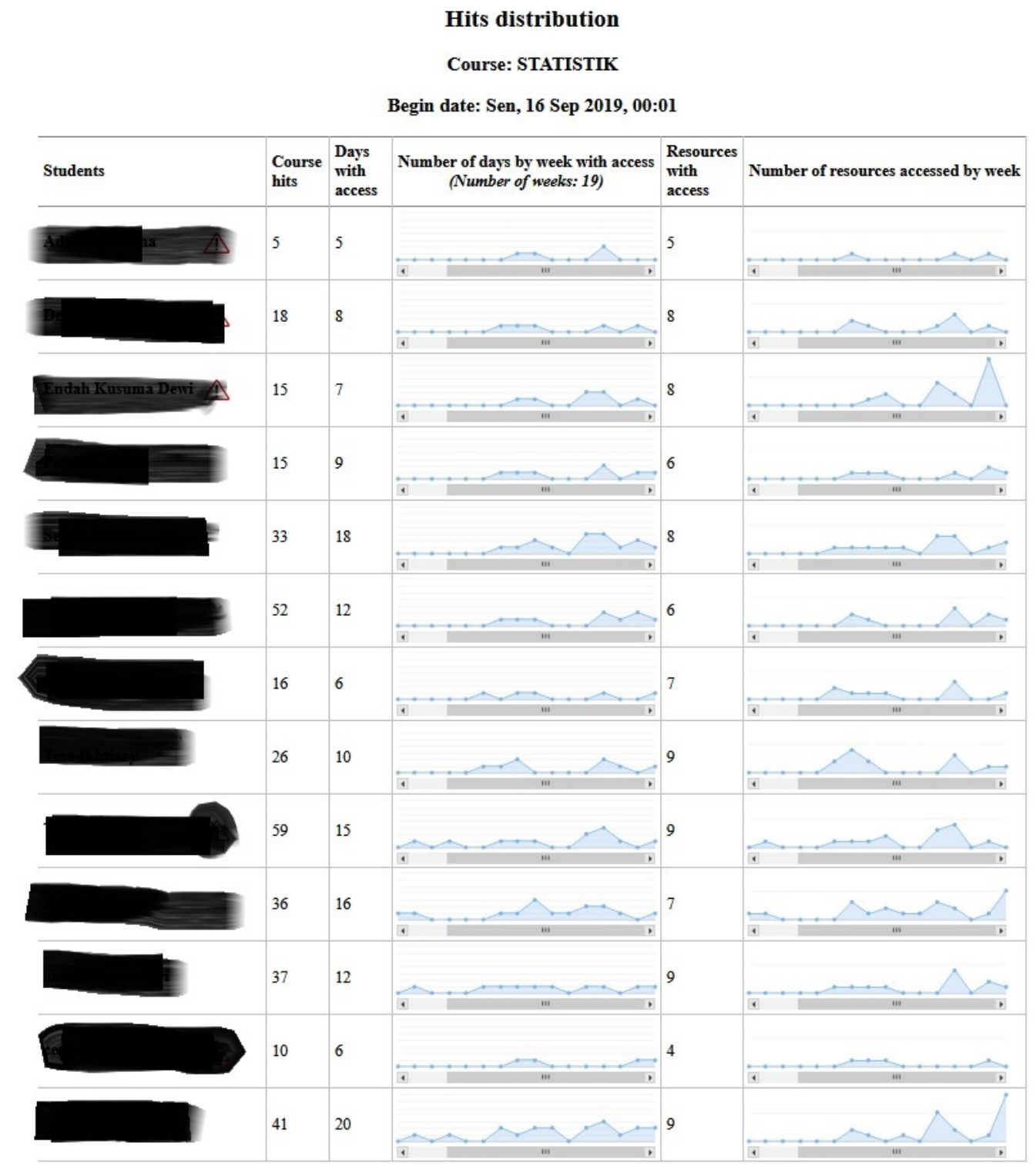

Figure 1. The Statistics Results of Students Attendance on the E-learning Session

Table 1. The learning outcomes and the active involvement score of Physics pre-service teacher

\begin{tabular}{ccc}
\hline No Respondent & Active Involvement Score & Learning Outcomes \\
\hline 1. & 65 & 81.6 \\
2. & 76 & 82 \\
3. & 88.5 & 82 \\
4. & 44 & 55 \\
5. & 65 & 80.8 \\
6. & 70.5 & 83.3 \\
7. & 60 & 80.4 \\
8. & 78 & 81.6 \\
9. & 75.5 & 81 \\
10. & 81 & 84.2 \\
11. & 68 & 80.6 \\
12. & 65 & 79 \\
13. & 65 & 80 \\
\hline
\end{tabular}

The data of the research results that are presented in Table 1 were then process and analyzed by using IBM SPSS 24 . Statistical testing was conducted to identify the influence and relationship of 
Momentum: Physics Education Journal, 4 (1), 2020, 34

Andista Candra Yusro, Mislan Sasono, Gilang Primayoga

the active involvement exhibited by Physics pre-service teacher on blended learning session toward the learning outcomes of Statistics course. Table 2 illustrates the results of correlation by using IBM SPSS 24.

Table 2. Output correlations Generated from IBM SPPS 24

\begin{tabular}{llrr}
\multicolumn{2}{c}{ Correlations } & \\
\hline Active Involvement & Active Involvement & Learning Outcomes \\
& Pearson Correlation & 1 & $.752^{* *}$ \\
& Sig. (2-tailed) & .003 \\
& Sum of Squares and Cross-products & 1483.308 & 746.412 \\
& Covariance & 123.609 & 62.201 \\
& $\mathrm{~N}$ & 13 & 13 \\
Learning Outcomes & $.752^{* *}$ & 1 \\
& Pearson Correlation & .003 & 664.252 \\
& Sig. (2-tailed) & 746.412 & 55.354 \\
& Sum of Squares and Cross-products & 62.201 & 13 \\
& Covariance & 13 & \\
& $\mathrm{~N}$ & & \\
\hline
\end{tabular}

**. Correlation is significant at the 0.01 level (2-tailed).

According to Table 2 above, the correlation value Sig (2-tailed $=0,003)<1 / 2 \alpha(0,025)$. It further means that the Ho was rejected. Thus, there is a positive correlation between the active involvement of Physics pre-service teachers on blended learning session on the learning outcomes of Statistics course. It signifies that the more the Physics pre-service teachers actively involve on the learning process, the higher learning outcomes they obtain. Furthermore, to identify the influence between the active involvement of Physics pre-service teacher on the learning outcomes of Statistics course, it is presented in the following Table 3.

Table 3. Model Summary output IBM SPSS 24

\begin{tabular}{cc|c|c|c}
\multicolumn{5}{c}{ Model Summary } \\
\hline Model & $\mathrm{R}$ & R Square & Adjusted R Square & Std. Error of the Estimate \\
\hline 1 & $.752^{\mathrm{a}}$ & .565 & .526 & 5.1226 \\
\hline
\end{tabular}

a. Predictors: (Constant), Active involvement

Table 3 presenting Model Summary that indicates a value of $R=0.751$ as the obtained value of correlation coefficient. Meanwhile, the R Square value obtained was 0.565 or it can further mean that the contribution of the active involvement of Physics pre-service teacher on blended learning session was $56.5 \%$ on the learning outcomes of Statistics course. Students merely understood that the process of e-learning session is limited to downloading lesson material and uploading the assignment only (Ali, 2007). Thus, the contribution of the active involvement of Physics pre-service teachers during this research was moderately significant. In general, blended learning demands students to be independent in the learning process (Wijaya, Suweken, \& Mertasari, 2017). The independent learning in this context does not mean that the students learn by themselves without any direction, but it means that the students show a sufficient awareness and consciousness in the learning process. Furthermore, it needs to be emphasized that blended learning is different from online learning. Blended learning comprises of both online learning session and conventional face-to-face session in a balance portion (Jeffrey et al., 2014; Kim et al., 2008).

According to table 4 , it obtained the value of $\operatorname{Sig}(0,03)<\alpha(0,05)$. Thus, it further means that Ho was rejected. The results signify that there is a linear correlation between the active involvement of Physics pre-service teachers and the learning outcomes of Statistics course. Based on Table 5, it obtained a correlation equation model of $Y=44.509+0.503 \mathrm{X}$. In addition to the active involvement of Physics pre-service teachers, there is another factor that influences the learning outcomes of Statistics course with a percentage of $44.5 \%$. 
Momentum: Physics Education Journal, 4 (1), 2020, 35

Andista Candra Yusro, Mislan Sasono, Gilang Primayoga

Table 4. ANOVA output IBM SPPS 24

\begin{tabular}{llccccc}
\multicolumn{7}{c}{ ANOVA $^{\mathrm{a}}$} \\
\hline Model & Sum of Squares & $\mathrm{df}$ & Mean Square & $\mathrm{F}$ & Sig. \\
\hline 1 & Regression & 375.600 & 1 & 375.600 & 14.313 & $.003^{\text {b }}$ \\
& Residual & 288.652 & 11 & 26.241 & & \\
& Total & 664.252 & 12 & & \\
\hline
\end{tabular}

a. Dependent Variable: Learning Outcomes

b. Predictors: (Constant), Active Involvement

Tabel 5. Coefficients Output SPSS 24

\begin{tabular}{|c|c|c|c|c|c|c|}
\hline \multicolumn{7}{|c|}{ Coefficients $^{\mathrm{a}}$} \\
\hline \multirow{2}{*}{\multicolumn{2}{|c|}{ Model }} & \multicolumn{2}{|c|}{ Unstandardized Coefficients } & \multirow{2}{*}{$\begin{array}{c}\text { Standardized Coefficients } \\
\text { Beta }\end{array}$} & \multirow{2}{*}{$\mathrm{t}$} & \multirow{2}{*}{ Sig. } \\
\hline & & $\mathrm{B}$ & Std. Error & & & \\
\hline \multirow[t]{2}{*}{1} & (Constant) & 44.509 & 9.317 & & 4.777 & .001 \\
\hline & Keaktifan & .503 & .133 & .752 & 3.783 & .003 \\
\hline
\end{tabular}

a. Dependent Variable: Learning Outcomes

The responses given by the Physics pre-service teachers regarding blended learning session on Statistics course are summarized into three major aspects. They are: (1) the ease of learning aspect; (2) the attractiveness learning process aspect; and (3) the ease of interaction aspect. The ease of learning aspect in blended learning session for Statistics course obtained a percentage of $80.67 \%$. the attractiveness learning process aspect in blended learning session for Statistics course obtained a percentage of $82.35 \%$. While, the ease of interaction aspect in blended learning for Statistics course obtained a percentage of $81.48 \%$. To be able to conduct blended learning session, teachers need to take into account the infrastructure aspects, particularly the internet connection that highly influences to the process of online learning session (Okaz, 2015; Porter \& Graham, 2016). Further-more, in terms of graphical presentation, the responses given by Physics pre-service teachers is illustrated in Figure 2 .

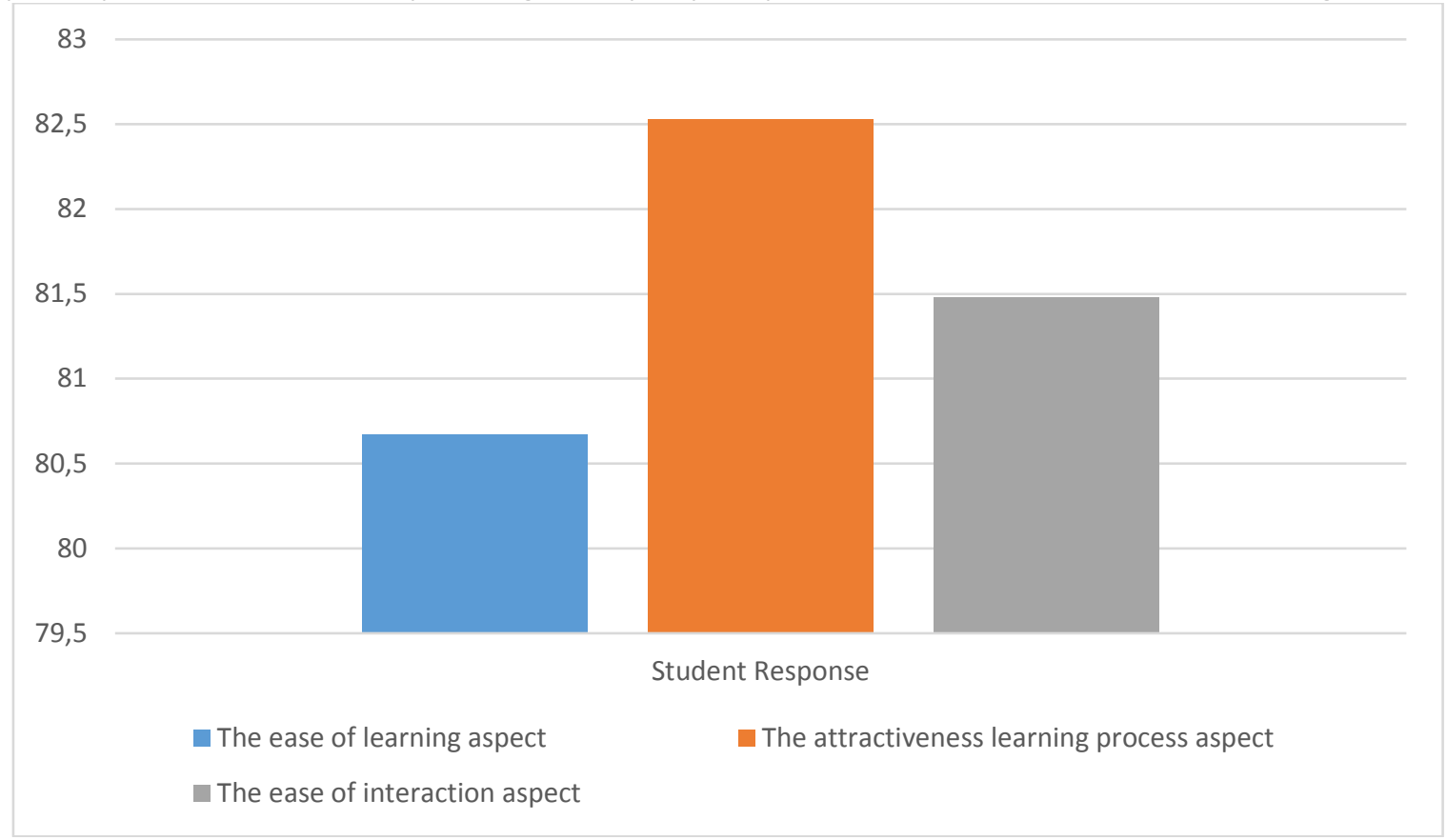

Figure 2. The Responses Given by Physics Pre-service Teachers on Blended Learning Session for Statistics Course

Based on the Figure 2, the ease of learning aspect obtained the lowest responses from the Physics pre-service teacher compare to the other aspects. This is because blended learning is rela-tively new learning procedure for the Physics pre-service teacher. They encountered some obstacles in the beginning of learning session. The obstacles were related to the access to e-learning and the access to 
resources. Some students were also difficult to send and upload the assignments within e-learning platform. However, as time went by, the Physics pre-service teachers were accustomed to learn with blended learning procedure. Basically, the online learning session in blended learning session assists both the lecturer and students in terms of space and time limitation during the face-to-face session. The preparation of the infrastructures and human resources, from both the lecturer and students, contribute the learning process (Garrison \& Vaughan, 2008).

\section{Conclusion}

Based on the results of the research, the active involvement of Physics pre-service teachers during blended learning session on Statistics course contributes as much as $56.5 \%$. While the correlation equation obtained was $Y=44.509+0.503 X$. The average responses of blended learning given by the Physics pre-service teacher on Statistics course was $81.5 \%$. The responses cover three aspects of assessment. Initial education in the beginning of the course is expected to be able to increase the understanding of students about e-learning implementation. Last but not least, the Physics pre-service teachers in this research were contended in the implementation of blended learning for Statistics course; it is further indicated by the responses given after the learning.

\section{References}

Afifah, S. N., \& Wicaksana, E. J. (2017). Persepsi mahasiswa tentang mata kuliah statistik serta pengaruhnya terhadap prestasi belajar statistik mahasiswa IKIP PGRI Madiun. Jurnal CARE (Children Advisory Research and Education), 2(1).

Alammary, A., Sheard, J., \& Carbone, A. (2014). Blended learning in higher education: Three different design approaches. Australasian Journal of Educational Technology, 30(4).

Ali, M. (2007). Analisis dampak implementasi model blended learning: Kombinasi pembelajaran di kelas dan e-learning pada mata kuliah medan elektromagnetik. Laporan Penelitian. UNY.

Divayana, D. G. H. (2017). Evaluasi pelaksanaan blended learning di SMK TI Udayana menggunakan model CSE-UCLA. Jurnal Pendidikan Vokasi, 7(1), 64-77.

Draper, N. R., \& Smith, H. (1998). Applied regression analysis (Vol. 326): John Wiley \& Sons.

Effendi, M. (2016). Integrasi pembelajaran active learning dan internet-based learning dalam meningkatkan keaktifan dan kreativitas belajar. Nadwa, 7(2), 283-309.

Field, A. (2009). Discopering Statistics using SPSS, Thrid Edition. In: Sage Publications.

Garrison, D. R., \& Vaughan, N. D. (2008). Blended learning in higher education: Framework, principles, and guidelines: John Wiley \& Sons.

Hudha, M. N., Chaeruman, U. A., Aji, S. D., Huda, C., Yusro, A. C., Kumala, F. N., . . Abdullah, A. G. (2018). SPADA: Online learning between universities of PGRI Indonesia. Paper presented at the MATEC Web of Conferences.

Jeffrey, L. M., Milne, J., Suddaby, G., \& Higgins, A. (2014). Blended learning: How teachers balance the blend of online and classroom components. Journal of Information Technology Education, 13.

Kim, K. J., Bonk, C. J., \& Oh, E. (2008). The present and future state of blended learning in workplace learning settings in the United States. Performance Improvement, 47(8), 5-16.

Kirna, I. M. (2014). Pengembangan konten online untuk mendukung blended learning pada perkuliahan kimia kuantum dasar. Jurnal Cakrawala Pendidikan, 33(2).

Kusni, M. (2010). Implementasi sistem pembelajaran blended learning pada kuliah AE3121 getaran mekanik di Program Studi Aeronotika dan Astronotika. Paper presented at the ITB, disajikan dalam Seminar Nasional Tahunan Teknik Mesin (SNTTM) ke-9 Palembang.

Liu, R., Kuang, J., Gong, Q., \& Hou, X. (2003). Principal component regression analysis with SPSS. Computer methods and programs in biomedicine, 71(2), 141-147. 
López-Pérez, M. V., Pérez-López, M. C., \& Rodríguez-Ariza, L. (2011). Blended learning in higher education: Students' perceptions and their relation to outcomes. Computers \& Education, 56(3), 818-826.

McCray, G. E. (2000). The hybrid course: Merging on-line instruction and the traditional classroom. Information Technology and Management, 1(4), 307-327.

Mendez, J. A., \& Gonzalez, E. J. (2011). Implementing motivational features in reactive blended learning: Application to an introductory control engineering course. IEEE Transactions on Education, 54(4), 619-627.

Mubarok, A. (2015). Peningkatan keaktifan belajar melalui penerapan metode blended learning dengan pendekatan pembelajaran tatap muka di kelas dan social network facebook pada kompetensi sistem transmisi siswa SMK Pancasila Surakarta. Jurnal Nosel, 3(4).

Muis, A., \& Bahri, A. (2018). Respon guru dan siswa SMA terhadap penggunaan Quipper School dalam blended learning pada pembelajaran biologi. Biology Teaching and Learning, 1(2), 167171.

Murni, D., \& Hodijah, S. R. N. (2016). Pengaruh blended learning berbasis scaffolding terhadap hasil belajar mahasiswa pada konsep substansi genetika.

Okaz, A. A. (2015). Integrating blended learning in higher education. Procedia-Social and Behavioral Sciences, 186, 600-603.

Porter, W. W., \& Graham, C. R. (2016). Institutional drivers and barriers to faculty adoption of blended learning in higher education. British Journal of Educational Technology, 47(4), 748762.

Porter, W. W., Graham, C. R., Spring, K. A., \& Welch, K. R. (2014). Blended learning in higher education: Institutional adoption and implementation. Computers \& Education, 75, 185-195.

Purwitasari, D., Astawa, I., \& Sudiarta, I. (2019). Penerapan blended learning berbantuan schoology untuk meningkatkan keaktifan dan prestasi belajar matematika siswa kelas VIII A1 SMP Negeri 6 Singaraja. Jurnal Pendidikan dan Pembelajaran Matematika Indonesia, 8(2), 143-152.

Santoso, A. B., Yusro, A. C., Malawi, I., Hanif, M., \& Kokotiasa, W. (2019). Evaluation of the application of information technology and communication in lectures in the Primary School Teacher Education Study Program. Paper presented at the Journal of Physics: Conference Series.

Seber, G. A., \& Lee, A. J. (2012). Linear regression analysis (Vol. 329): John Wiley \& Sons.

Sofiana, N. (2015). Implementasi blended learning pada mata kuliah extensive listening. Tarbawi: Jurnal Pendidikan Islam, 12(1).

Subekti, F. E., Untarti, R., \& Muhammad, M. (2016). Deskripsi kemampuan komunikasi matematis mahasiswa pada mata kuliah statistik pendidikan. Euclid, 2(2).

Vaughan, N. (2007). Perspectives on blended learning in higher education. International Journal on Elearning, 6(1), 81-94.

Widiyanto, T. (2015). Peningkatan keaktifan dan hasil belajar kompetensi dasar pembentukan logam dengan blended learning berbantuan media sosial schoology di kelas X TKRD SMK Negeri 2 Surakarta. Jurnal Nosel, 4(1).

Wijaya, I., Suweken, G., \& Mertasari, N. (2017). Pengaruh penerapan model pembelajaran blended learning terhadap motivasi berprestasi dan prestasi belajar matematika siswa SMA Negeri 1 Singaraja. Wahana Matematika dan Sains: Jurnal Matematika, Sains, dan Pembelajarannya, 10(2), 36-47.

Yusro, A. C. (2018). Kemampuan Calon guru fisika dalam penguasan TIK dan media pembelajaran berbasis ICT di Era Revolusi Industri 4.0. Paper presented at the SNPF 2018: Peran Pendidik dan IImuan Sains dalam Meyongsong Revolusi Industri 4.0. 